\title{
Accompaniment Learning Media Development to Increase The Elementary School Teacher Competence
}

\author{
Wahyudi, Muhamad Chamdani, Kartika Chrysti Suryandari, Rokhmaniyah \\ Universitas Sebelas Maret \\ wahyudi@fkip.uns.ac.id
}

\section{Article History}

accepted 24/09/2019

\begin{abstract}
One of the problems faced by elementary school teachers is the problem of making and using learning media in schools. This is due to the lack of readiness of human resources about understanding media in learning. For this purpose the community service activities are: (1) increasing the competence of elementary school teachers about learning, (2) developing learning media in elementary schools, (3) structuring learning media in elementary schools. This Community Service activity uses the design of the transfer of science and technology from the university to the stakeholders which includes: (a) workshops, (b) training and mentoring. This dedication activity was carried out in the activities of the Teachers Working Group Cluster "Banyumudal" in Kebumen District year 2019. The results of these community service activities are: (1) improvement of teacher competency about learning media in elementary schools, (2) products of various types of learning media in elementary schools, (3) the formation of "Mini Laboratory" for learning in elementary schools.
\end{abstract}

Keywords: Accompaniment, Learning Media, Elementary School

\section{Abstrak}

Salah satu masalah yang dihadapi guru sekolah dasar adalah masalah pengadaan, pembuatan, dan penggunaan media pembelajaran di sekolah. Hal ini disebabkan kurangnya kesiapan sumber daya manusia tentang pemahaman media dalam pembelajaran. Untuk itu tujuan kegiatan pengabdian kepada masyarakat ini adalah: (1) meningkatkan kompetensi guru sekolah dasar tentang pembelajaran, (2) pengembangan media pembelajaran di sekolah dasar, (3) penataan Media pembelajaran di sekolah dasar. Kegiatan Pengabdian kepada Masyarakat ini menggunakan desain Transfer ilmu pengetahuan dan teknologi dari perguruan tinggi kepada stake holder yang meliputi kegiatan: (a) workshop, (b) pelatihan dan pendampingan Kegiatan pengabdian ini dilaksanakan dalam kegiatan Kelompok Kerja Guru Gugus "Banyumudal" di Kecamatan Kebumen Tahun 2019. Hasil dari kegiatan pengabdian ini adalah: (1) peningkatan kompetensi guru tentang media pembelajaran di sekolah dasar, (2) produk berbagai jenis media pembelajaran di sekolah dasar, (3) terbentuknya "Laboratorium Mini" untuk pembelajaran di sekolah dasar.

Kata Kunci: Pendampingan, Media Pembelajaran, Sekolah Dasar

\begin{tabular}{ll}
\hline Social, Humanities, and Education Studies (SHEs): Conference Series & p-ISSN 2620-9284 \\
https://jurnal.uns.ac.id/shes & e-ISSN 2620-9292
\end{tabular}




\section{PENDAHULUAN}

Indonesia sebagai negara berpopulasi tertinggi ke-4 di dunia tentunya memiliki tantangan yang sama dengan Negara-negara besar lainnya. Tentunya juga memiliki tantangan khusus di bidang pendidikan. Beberapa tantangan dalam bidang pendidikan di antaranya adalah: (1) masih banyaknya anak usia sekolah yang belum dapat menikmati pendidikan dasar 9 tahun, (2) tidak meratanya penyebaran sarana dan prasarana pendidikan/sekolah (sebagai contoh: tidak semua sekolah memiliki saluran telepon, apalagi koneksi internet), (3) tidak seragamnya dan masih rendahnya mutu pendidikan di setiap jenjang sekolah yang ditandai dengan tingkat kelulusan UN yang masih rendah, demikian pula nilai UN yang diperoleh siswa, (4) rendahnya kualitas kompetensi tenaga pengajar, dan (5) rendahnya tingkat pemanfaatan TIK di sekolah yang telah memiliki fasilitas TIK (utilitas rendah), di sisi lain tidak semua sekolah mempunyai sarana TIK yang memadai.

Undang-undang No. 20 tahun 2003 tentang Sistem Pendidikan Nasional telah mengamanatkan bahwa pendidik merupakan tenaga profesional yang bertugas merencanakan dan melaksanakan proses pembelajaran, menilai hasil pembelajaran, melakukan pembimbingan dan pelatihan, serta melakukan penelitian dan pengabdian kepada masyarakat, terutama bagi pendidik pada perguruan tinggi. Untuk itu Pendidik wajib memiliki kualifikasi akademik, kompetensi, sertifikat pendidik, sehat jasmani dan rohani, serta memiliki kemampuan untuk mewujudkan tujuan pendidikan nasional.

Kompetensi adalah seperangkat pengetahuan, keterampilan, dan perilaku yang harus dimiliki, dihayati, dan dikuasai oleh guru atau dosen dalam melaksanakan tugas keprofesionalan. Kompetensi guru yang diharuskan dimiliki seorang pendidik meliputi kompetensi pedagogik, kompetensi kepribadian, kompetensi sosial, dan kompetensi profesional yang diperoleh melalui pendidikan profesi.

Hasil pengamatan dan studi pendahuluan di wilayah UPT Dikpora Kecamatan Kebumen-Kabupaten Kebumen yang dilaksanakan pada semester genap tahun pelajaran 2018/2019, menunjukkan bahwa untuk mencapai kompetensi paedagogik dan kompetensi professional guru, masih banyak kendala yang dialami para guru, khususnya guru sekolah dasar. Masalah pembuatan, penggunaan media pembelajaran dan Pemanfaatan Teknologi Informasi dan Komunikasi (TIK) untuk pembelajaran di sekolah dasar juga masih dirasakan sebagai kendala yang berat. Hal ini disebabkan beberapa hal, di antaranya adalah: (1) kurangnya kesiapan sumber daya manusia (SDM) tentang pemahaman media dalam pembelajaran, (2) kurangnya pemahaman tentang pembelajaran berbasis media, (3) kurangnya sarana media \& TIK untuk pembelajaran, (4) manajemen media dan TIK yang belum terprogram, Untuk itu dalam rangka penyiapan dan peningkatan kompetensi SDM dan pemahaman tentang pembelajaran berbasis media masih sangat diperlukan.

Berdasarkan kondisi rill di lapangan tersebut, maka Tim Pengabdian kepada Masyarakat Program Studi PGSD FKIP UNS Kampus Kebumen merasa terpanggil untuk menindaklanjuti permasalahan tersebut, yaitu dengan melaksanakan kegiatan pendampinan tentang pembuatan, penggunaan, dan penataan media pembelajaran di sekolah dasar di wilayah UPT Dikpora Kecamatan Kebumen - Kabupaten Kebumen. Tujuan umum kegiatan pengabdian kepada masyarakat ini adalah untuk meningkatkan pemahaman dan kompetensi guru sekolah dasar pada penggunaan media pembelajaran di sekolah dasar. Sedangkan tujuan khusus kegiatan pengabdian kepada masyarakat ini adalah sebagai berikut (1) meningkatkan pemahaman guru sekolah dasar tentang pembelajaran berbasis Kurikulum 2013, (2) pengembangan Media pembelajaran berbasis Kurikulum 2013 di sekolah dasar, (3) penataan/manajemen Media pembelajaran di sekolah dasar. 


\section{METODE}

Kegiatan Pengabdian kepada Masyarakat ini menggunakan desain Transfer ilmu pengetahuan dan teknologi dari perguruan tinggi kepada stake holder yang meliputi kegiatan: (a) workshop, (b) pelatihan dan pendampingan, dan (c) pengembangan hasil pelatihan berupa pembentukan laboratorium mini di sekolah dasar. Kegiatan pengabdian ini dilaksanakan selama 6 minggu dalam bentuk kegiatan Kelompok Kerja Guru (KKG) Gugus "Banyumudal" di Kecamatan Kebumen, Kabupaten Kebumen Tahun 2019. Kelompok Gugus Banyumudal meliputi 5 (lima ) sekolah dasar, yang terdiri dari 4 sekolah dasar negeri dan 1 sekolah dasar swasta. Guru yang terlibat pada kegiatan ini sebanyak 42 orang dan 5 kepala sekolah dasar. Dengan demikian kegiatan pengabdian ini menggunakan sumber data dari guru SD, kepala SD, dosen dan dokumen.

Dalam mengumpulkan data selama pelaksanaan kegiatan pengabdian berlangsung, pengabdi menggunakan berbagai teknik pengumpulan data, yaitu (a) observasi, (b) wawancara, (c) dokumen, (d) hasil unjuk kerja. Adapun untuk menjaga keabsahan data atau validitas data, pengabdi menggunakan teknik triangulasi sumber data dan triangulasi teknik pengumpulan data yang melibatkan guru SD, kepala sekolah, mahasiswa, dan teman sejawat (rekan dosen).

Analisis data yang digunakan dalam pengabdian ini adalah analisis data deskriptif-kualitatif yang meliputi tiga alur kegiatan yang dilakukan secara bersamaan dan terus menerus selama dan setelah pengumpulan data yaitu (1) reduksi data, (2) penyajian data, dan (3) penarikan kesimpulan atau verifikasi data. Prosedur pengabdian ini diuraikan menjadi 3 bagian, yaitu (1) analisis kebutuhan, (2) kegiatan workshop, (3) kegiatan Pelatihan dan pendampingan, dan (4) kegiatan penataan/manajemen.

\section{HASIL DAN PEMBAHASAN}

Berdasarkan rencana kegiatan pengabdian, maka rangkaian kegiatan pengabdian yang telah dilaksanakan meliputi: (1) rapat koordinasi kegiatan pengabdian, (2) analisis kebutuhan Media Pembelajaran, (3) workshop Media Pembelajaran Berbasis Kurikulum 2013, (4) pelatihan dan pendampingan pembuatan Media Pembelajaran, (5) penataan Media Pembelajaran di sekolah.

Pertemuan pertama pada kegiatan pengabdian adalah kegiatan sosialisasi dan koordinasi dilaksanakan pada pertemuan pertama Kegiatan ini diikuti oleh seluruh 5 kepala sekolah dan 42 guru kelas yang berada di wilayah Gugus Banyumudal Kecamatan Kebumen. Tujuan acara ini adalah untuk menyamakan persepsi tentang kegiatan yang akan dilaksanakan.

Pertemuan kedua berupa kegiatan diskusi analisis kebutuhan Media Pembelajaran. Tujuan acara ini adalah untuk menemukan simpulan prioritas kebutuhan tentang Mendia Pembelajaran Berbasis Kurikulum 2013 yang akan ditindaklanjuti pada kegiatan berikutnya. Adapun hasil analisis kebutuhan tentang Media Pembelajaran adalah sebagai berikut

Tabel 1: Hasil Analisis Kebutuhan Media Pembelajaran di Sekolah Dasar

\begin{tabular}{lll}
\hline \multicolumn{1}{c}{ Mata Pelajaran } & \multicolumn{1}{c}{ Media Pembelajaran yang diperlukan } \\
\hline Matematika & 1. Ular Pintar (Mengurutkan Bilangan \\
& 2. Kantong Operasi Penjumlahan \& Pengurangan \\
3. Kotak Bilangan/Rak Bilangan \\
4. Alat Peraga Pembagian (Porogapit) \\
5. Alat Peraga Bilangan Bulat \\
6. Kerangka Bangun Ruang \\
7. Alat Peraga Pecahan \\
8. Alat Peraga Volume Bangun Ruang \\
9. Timbangan Dacin (Alat Ukur Berat)
\end{tabular}




\begin{tabular}{ll}
\hline IPA & 1. Video Alat indera Pendengaran \\
& 2. Video Pembuatan energi alternatif \\
& 3. Rangka manusia \\
& 4. Torso \\
& 5. Alat Peraga Planetarium \\
& 6. Alat Peraga Gerhana \\
& 7. Media Lampu Lalulintas \\
\hline IPS & 1. Peta Keberagaman Budaya \\
& 2. Video Tarian/Keberagaman Budaya \\
& 3. Atlas Indonesia \\
& 4. Keragaman Suku Bangsa di Indonesia \\
& 5. Alat Peraga Bencana \\
& 6. Kartu Pahlawan \\
\hline Bahasa Indonesia & 1. Papan Silsilah Keluarga \\
& 2. Gambar Berseri \\
& 3. Video Cerita Rakyat \\
& 4. Buku Cerita Rakyat \\
5. Cara Mudah Menyusun Paragraf \\
\hline SBdP/SBK & 1. Alat Musik Tradisional \\
& 2. Alat-alat Seni Rupa \\
3. Guru Seni Musik \\
4. Guru Seni rupa
\end{tabular}

Berdasarkan analisis kebutuhan tersebut di atas, maka dihasilkan alternatif solusi yang ditawarkan pada kegiatan pengabdian sebagai berikut.

Tabel 2: Solusi yang ditawarkan pada Kegiatan Pengabdian

\begin{tabular}{|c|c|c|c|c|}
\hline No & $\begin{array}{l}\text { Permasalahan } \\
\text { sekolah }\end{array}$ & $\begin{array}{l}\text { Solusi yang } \\
\text { ditawarkan }\end{array}$ & Aspek & $\begin{array}{c}\text { Partisipasi } \\
\text { Mitra }\end{array}$ \\
\hline 1 & $\begin{array}{l}\text { Pemahaman } \\
\text { Pembelajaran } \\
\text { berbasis Kurikulum } \\
2013 \text { belum } \\
\text { memadai }\end{array}$ & $\begin{array}{l}\text { Workshop tentang } \\
\text { Pembelajaran } \\
\text { Berbasis Kurikulum } \\
2013 .\end{array}$ & Manajemen & $\begin{array}{l}\text { Peserta } \\
\text { (47 orang) }\end{array}$ \\
\hline 2 & $\begin{array}{l}\text { Media Pembelajaran } \\
\text { Berbasis Kurikulum } \\
2013 \text { belum } \\
\text { memadai }\end{array}$ & $\begin{array}{l}\text { Pelatihan dan } \\
\text { Pendampingan } \\
\text { Pembuatan Media } \\
\text { Pembelajaran } \\
\text { berbasis Kurikulum } \\
2013 .\end{array}$ & Produksi & $\begin{array}{l}\text { Peserta } \\
\text { (47 orang) }\end{array}$ \\
\hline 3 & $\begin{array}{l}\text { Manajemen Media } \\
\text { Pembelajaran belum } \\
\text { terprogram }\end{array}$ & $\begin{array}{l}\text { Penataan \& } \\
\text { manajemen media } \\
\text { Pembelajaran di SD } \\
\text { dalam bentuk } \\
\text { "Pameran" }\end{array}$ & $\begin{array}{l}\text { Manajemen } \\
\text { Produksi }\end{array}$ & $\begin{array}{l}\text { Peserta } \\
\text { (47 orang) }\end{array}$ \\
\hline
\end{tabular}

Pertemuan ketiga berupa kegiatan workshop tentang pemahaman dan pemanfaatan media pada pembelajaran berbasis kurkulum 2013. Materi workshop meliputi: (a) Media Pembelajaran Bahasa Indonesia, (b) Media Pembelajaran Matematika, (c) Media Pembelajaran IPA, (d) Media Pembelajaran IPS, dan (5) Media Pembelajaran Seni Budaya dan Prakarya (SBdP). Tujuan workshop adalah untuk meningkatkan pemahaman dan keterampilan guru sekolah dasar dalam pemanfaatan, 
penggunaan, pembuatan, dan penataan media pembelajaran untuk siswa sekolah dasar berbasis Kurikulum 2013. Kegiatan workshop dipandu oleh 5 dosen pendamping sesuai dengan kelompok mata pelajaran, yaitu bahasa Indonesia, Matematika, IPA, IPS, dan Seni Budaya dan Keterampilan (SBK). Berdasarkan hasil kegiatan Workshop yang telah dilaksanakan, maka pemahaman guru terhadap media pembelajaran semakin meningkat. Hal ini ditunjukkan dengan antusias dan keaktifan peserta pada saat mengikuti workshop. Peningkatan pemahaman guru juga terlihat ketika dilakukan pembahasan tentang pemanfaatan, penggunaan, dan pembuatan media pembelajaran. Setelah pemahaman terhadap Media Pembelajaran dimiliki oleh guru lebih meningkat, maka kegiatan selanjutnya adalah praktik mengembangkan Media Pembelajaran, yaitu merancang dan membuat media pembelajaran sesuai dengan daftar perencanaan pengembangan Media Pembelajaran yang telah disusun oleh masing-masing guru kelas.

Pertemuan keempat dan kelima adalah kegiatan pelatihan dan pendampingan pembuatan Media Pembelajaran Berbasis Kurikulum 2013. Tujuan pelatihan dan pendampingan adalah untuk melatih dan mendampingi secara langsung kepada guruguru sekolah dasar dalam perencanaan dan pembuatan Media Pembelajaran Berbasis Kurikulum 2013. Kegiatan ini merupakan Inti pengabdian kepada masyarakat. Kegiatan pelatihan dan pendampingan dipandu dan didampingi oleh 5 dosen pendamping berdasarkan kelompok mata pelajaran. Kegiatan pelatihan dan pendampingan meliputi kegiatan perencanaan dan kegiatan pembuatan media pembelajaran. Kegiatan perencanaan dan pembuatan media pembelajaran dilaksanakan secara bertahap. Kegiatan perencanaan dilakukan pada saat pertemuan di tingkat gugus melalui kegiatan diskusi dengan teman-teman sejawat guru kelas masing-masing, yaitu kelompok guru kelas I, II, III, IV, V, dan VI. Hasil diskusi di tingkat gugus tersebut dijadikan pedoman bersama untuk pembuatan media pembelajaran. Mengingat terbatasnya waktu pertemuan di tingkat gugus, maka tahap pembuatan media pembelajaran dilaksanakan di tingkat gugus dan dilanjutkan di rumah masing-masing. Selanjutnya hasil pembuatan media pembelajaran tersebut dibawa pada saat pertemuan berikutnya di tingkat gugus. Dengan demikian setiap guru dapat melihat dan memberi apresiasi hasil pekerjaan teman sejawatnya sesuai dengan kelas masing-masing. Dari kegiatan pelatihan dan pendampingan tersebut dapat menghasilkan berbagai jenis media pembelajaran yang dapat dimanfaatkan guru dalam pembelajaran berbasis Kurikulum 2013.

Tabel 3: Hasil Pengembangan Media Pembelajaran

\begin{tabular}{ll}
\hline \multicolumn{1}{c}{ Mata Pelajaran } & \multicolumn{1}{c}{ Media Pembelajaran yang dikembangkan Guru } \\
\hline Matematika & $\begin{array}{l}\text { 1. Kantong Operasi Penjumlahan \& Pengurangan } \\
\text { 2. Kotak Bilangan/Rak Bilangan }\end{array}$ \\
& $\begin{array}{l}\text { 3. Fakta Dasar penjumlahan, pengurangan, perkalian, } \\
\text { dan pembagian }\end{array}$ \\
& $\begin{array}{l}\text { 4. Alat Peraga Bilangan Bulat (Muatan \& Flanel) } \\
\text { 5. Bangun Datar dan Daerah bangun datar }\end{array}$ \\
6. Kerangka Bangun Ruang \\
7. Alat Peraga Pecahan \\
8. Alat Peraga Volume Bangun Ruang (Limas, \\
IPA Kerucut, Bola) \\
9. Timbangan badan \\
1. Video Alat indera Pendengaran \\
2. Video Pembuatan energi alternatif \\
3. Rangka manusia \\
4. Roket \\
5. Alat Peraga Planetarium
\end{tabular}




\begin{tabular}{ll}
\hline & 6. Alat Peraga Gerhana \\
& 7. Media Lampu Lalulintas \\
\hline IPS & 1. Gambar Keberagaman Budaya \\
& 2. Video Tarian daerah/Keberagaman Budaya \\
3. Atlas Indonesia & 4. Keragaman Suku Bangsa di Indonesia \\
& 5. Kartu Pahlawan \\
\hline Bahasa Indonesia & 1. Papan Silsilah Keluarga \\
& 2. Nama Bagian Tubuh \\
3. Video Cerita Rakyat \\
4. Kartu Huruf dan Kartu Kata \\
5. Pias Kata \\
\hline SBdP/SBK & 1. Mozaik \\
2. Alat-alat Seni Rupa & 3. Gambar Tokoh Pewayangan
\end{tabular}

Berdasarkan hasil evaluasi dari kegiatan pelatihan dan pendampingan, maka dapat disimpulkan tingkat keberhasilan program mencapai $90 \%$ dari target yang direncanakan. Hal ini terjadi karena ada beberapa kebutuhan yang sangat mendesak tentang beberapa jenis media pembelajaran yang belum dapat dipenuhi pada kegiatan pengabdian saat ini dikarenakan keterbatasan waktu. Kecuali itu, kebutuhan tentang sumber daya manusia berupa tenaga ahli (guru khusus seni musik dan seni rupa) juga belum dapat dipenuhi pada kegiatan pengabdian saat ini. Guru khusus seni musik, seni rupa, dan bahasa Jawa sangat dibutuhkan untuk mendukung keberhasilan kegiatan pembelajaran maupun kegiatan ekstra kurikuler di sekolah dasar, tetapi kondisi di lapangan untuk memperoleh guru khusus tersebut masih sangat sulit.

Pertemuan keenam berupa kegiatan penataan media pembelajaran dalam bentuk "Pameran" tentang Media Pembelajaran yang telah dibuat dan dikembangkan oleh guru sekolah dasar. Tujuan kegiatan ini adalah untuk menata dan mengenalkan hasil karya guru tentang pembuatan Media Pembelajaran yang dapat digunakan untuk menunjang proses pembelajaran di sekolah dasar berbasis Kurikulum 2013. Kegiatan pameran ini disusun berdasarkan tingkatan kelas dalam suatu ruangan yang disediakan oleh gugus. Meja (Stand) pameran terdiri dari Stand Kelas I, Stand Kelas II, Stand Kelas III, Stand Kelas IV, Stand Kelas V, dan Stand Kelas VI. Masing-masing stand berisi hasil karya guru kelas yang berasal dari 5 sekolah yang ada di wilayah gugus Banymudal. Kegiatan dalam bentuk pameran ini sangat menarik, karena dapat dimanfaatkan oleh kepala sekolah, guru. dan siswa sekolah dasar. Manfaat bagi kepala sekolah adalah untuk memberikan motivasi dan apresiasi kepada guru kelas untuk selalu meningkatkan pemahaman, pemanfaatan, dan inovasi tentang media pembelajaran. Manfaat bagi guru kelas, selain memberikan susana refreshing adalah sebagai sarana untuk sharing kemampuan tentang perencanaan dan pembuatan media pembelajaran pada sesama guru kelas maupun antar guru kelas di tingkat gugus. Kecuali itu, kegiatan pameran juga dapat dimanfaatkan oleh para siswa sekolah dasar untuk lebih mengenal dan menggunakan media pembelajaran untuk meningkatkan pemahaman materi pembelajaran yang disajikan guru di kelas.

Kegiatan pameran merupakan kegiatan puncak pengabdian untuk memamerkan hasil kerja para guru SD dalam perancangan, pembuatan, dan penggunaan media pembelajaran. Kegiatan Pameran merupakan salah satu model penyajian hasil kerja bersama pada guru kelas SD di tingkat gugus Banyumudal. Kegiatan Pameran ini perlu ditindaklanjuti di sekolah masing-masing dalam bentuk "Laboratorium Mini" Media 
Pembelajaran. Dengan modal pengalaman yang diperoleh di tingkat gugus, maka dapat dimplementasikan secara lebih variatif dan inovatif di sekolah masing-masing.

\section{SIMPULAN}

Berdasarkan rumusan masalah, tujuan pengabdian dan hasil kegiatan yang telah dilaksanakan, maka dapat disimpulkan sebagai berikut.

1. Kegiatan pengabdian kepada masyarakat melalui workshop dan pendampingan dapat meningkatkan pemahaman guru sekolah dasar tentang pembelajaran berbasis Kurikulum 2013.

2. Kegiatan pengabdian kepada masyarakat melalui workshop dan pendampingan dapat meningkatkan pemahaman dan keterampilan guru sekolah dasar dalam pengembangan Media pembelajaran berbasis Kurikulum 2013.

3. Kegiatan pengabdian kepada masyarakat melalui workshop dan pendampingan, serta kegiatan pameran dapat mewujudkan bentuk model penataan/manajemen Media pembelajaran di sekolah dasar.

\section{DAFTAR PUSTAKA}

Purnomo, W. (2008). Pembelajaran Berbasis ICT. (Makalah disampaikan pada "Workshop Pembelajaran Berbasis ICT" di Dinas Pendidikan Propinsi Sulawesi Selatan, 11-14 Agustus 2008). http://wahyupur.blogspot.com

Pustekkom. (2010). Strategi Pembelajaran Berbasis TIK. Jakarta: Depdikbud

Undang-Undang Nomor 20 Tahun 2003 tentang Sistem Pendidikan Nasional. Jakarta: Sinar Grafika

Undang-Undang Nomor 14 Tahun 2005 tentang Guru dan Dosen. Jakarta: Sinar Grafika

Wahyudi dkk. (2012). Pendampingan Pembuatan Media dan Pemanfaatan Teknologi Informasi dan Komunikasi (TIK) untuk Pembelajaran di Sekolah Dasar bagi Guru SD di Kecamatan Karanggayam, Kabupaten Kebumen Tahun 2012. Surakarta: FKIP UNS.

Wahyudi, (2015). Panduan Pembelajaran Matematika SD (Untuk Guru dan Calon Guru SD). Surakarta: UNS Press.

Wena, M. (2009). Strategi Pembelajaran Inovatif Kontemporer (Suatu Tinjauan Konseptual Oprasional). Jakarta: Bumi Aksara 